\title{
Radon data processing and outputs for the needs of the State Office for Nuclear Safety (according to the Czech Radon Programme)
}

\author{
Jitka Mikšová and Ivan Barnet \\ Czech Geological Survey, Prague 1, Czech Republic
}

\begin{abstract}
Much of the population living in the Czech Republic is exposed to radiation from natural sources, especially to the radon effect. The aim of geological research defined by the State Office for Nuclear Safety (SONS) was to detect areas with estimated high radon concentration in soil gas. A uniform method of measurements and uniform methodology of radon risk category assessment of geological units and a centralized radon database was established. Radon risk classification was based on statistical evaluation of soil gas radon concentration and permeability in investigated geological units. Prognostic radon risk maps in various scales were the main outputs of this research. With the help of GIS tools spatial analyses were found a correlation between soil gas radon values in selected geological units and indoor measurements in dwellings. After verification of the efficiency of track etch detectors placed in dwellings with the help of prognostic maps $75 \%$ reliability of these maps was proven. This reliability of analyses induced the SONS to widely use radon risk maps to determine areas with predicted high radon risk category.
\end{abstract}

Key words radon-indoor-bedrock relationship radon mapping

\section{Introduction}

The Czech Geological Survey (CGS) has been participating in solving the problems of the inhabitants' irradiation caused by natural radionuclides since 1990 (Barnet, 1996).

The Radon Programme of the Czech Republic (CR) started within the scope of the Governmental Decision No. 538 in 1999. Present research on radionuclides in dwellings has revealed that the CR is one of the countries with the highest level of average ${ }^{222} \mathrm{Rn}$ concentration in buildings. Therefore great attention is paid to indoor Rn measurements.

Mailing address: Dr. Jitka Mikšová, Czech Geological Survey, Prague 1, Klárov 3, 11821 Czech Republic; email: miksova@cgu.cz
A number of houses above the guidance level of $200 \mathrm{Bqm}^{-3}$ of equilibrium equivalent concentration being detected in the last five years is given in table I.

The main target of research work was to process all data and information from available databases and approve the existing relationship between increased indoor radon values and rock types in bedrock considering that a significant part of the territory of the CR is formed by the Bohemian Massif, which belongs to the European Variscan belt represented by the Proterozoic and pre-Variscan Paleozoic crystalline basement. (Mísař et al., 1983). Similar studies were performed by Kies et al. (1996), Kemski et al. (2000), Popit and Vaupotic (2002).

\section{Data sources}

Geologically based radon data originates from CGS measurements and also from more than 100 private companies of the Association 
Table I. Number of indoor Rn measurements in the Czech Republic in 1998-2002.

\begin{tabular}{cccccc}
\hline \hline Year & Number of measured dwellings & \multicolumn{4}{c}{$\begin{array}{c}\text { Number of dwellings with range } \\
\text { of measured EEC }\left(\mathrm{Bqm}^{-3}\right)\end{array}$} \\
\hline & & $>200$ & $200-299$ & $300-600$ & $>600$ \\
\cline { 3 - 5 } 1998 & 5634 & 2014 & 925 & 773 & 316 \\
1999 & 5257 & 1171 & 533 & 455 & 183 \\
2000 & 6760 & 1570 & 668 & 684 & 218 \\
2001 & 11546 & 2150 & 1107 & 802 & 178 \\
2002 & 10841 & 1749 & 850 & 722 & 177 \\
\hline
\end{tabular}

Radon Risk. Data sources used for GIS applications come mostly from state organizations.

- Czech Geological Survey (CGS): Soil gas radon database (about 9000 test sites in different rock units), vectorized geological maps (214 map sheets $1: 50000)$.

- Czech Office for Surveying, Mapping and Cadastre: Raster topography.

- Ministry for Regional Development of the Czech Republic: Database - UIR (special data register of regional identification), contours of cadastres, database of residential units and other details of measured dwellings.

- National Radiation Protection Institute: Indoor radon database (indoor radon measurement - 130000 points, geometric mean in cadastre 6299 cadastres).

- Czech Statistical Office: Database of geographic position (of measured dwellings) and character of dwellings.

The field method of soil gas radon measurements and methodology of radon risk category assessments are standardized. A uniform method for soil gas radon measurements is used by all organization dealing with building site assessment.

The soil gas sample is taken from a depth of $0.8 \mathrm{~m}$ using rods with a «lost tip». At least 15 measurements are performed at each test site. The $75 \%$ quantile of radon data set serves as an input parameter for radon risk classification. The permeability is derived from grain-size analysis or from permeametric measurements in situ.

All subjects dealing with soil gas radon measurements pass the calibration of devices in radon chamber and field-testing at the reference sites to ensure the comparability and reliability of results. In the Czech Geological Survey the portable radonmeter RDA 200 (Scintrex) with exchangeable Lucas cells is used for soil gas radon measurements.

\section{Data processing}

All data are placed in a centralized database administrated by CGS. A sufficient number of measurements (nearly 9000 measured test site with 15 measurements and 29 items concerning localization, radon, geological and classification data for every test site) makes a statistically reliable data set to determine radon risk from bedrock in particular geological units and rock types (Mikšová and Barnet, 2002).

The construction of predictive radon risk maps is based on contours of geological units. The division of rock types into prevailing radon risk categories is done with the help of statistical methods using soil gas radon concentration and permeability. The predictive radon risk maps are not based on the uranium data from the territory of the Czech Republic but solely on the soil gas radon and permeability measurements (Mikšová and Barnet, 2002). The rock units are classified after prevailing radon risk category: low risk (mostly younger sediment formations from Cretaceous to Neogene), interstage risk (mostly inhomogeneous Quaternary sediments), medium risk (mostly Paleozoic sediments and crystalline gneisses), high risk (granitoids). 
The building projects of newly built houses are modified after the radon risk category measured on the building ground (Czech Technical Norm 730601, 1996).

The spatial analysis was made to find significant information on the relationship between soil gas radon concentration and indoor measurements. Three different approaches for spatial comparison of cadastre's polygons and contours of the geological units were tested. The way combining the demand for geographical preciseness and the demand for statistical reliability for further analyses was chosen. This method comprised the selection of cadastres with centroidal points situated inside the contour of rock unit, but the border of the cadastre was partially intersecting the contour of the geological unit (Barnet et al., 2002). An example of resulting selection performed by three methods is given for cadastres situated in the durba- chite bodies of Třebíč massif in Moravia (figs. 1, 2 and 3 ).

The indoor radon means calculated for different rock types on the basis of spatial analysis are given in table II. The «indoor intersection» values represent the results of the first method of analysis where polygons of cadastres are intersecting the polygons of geological units with no respect to ratio of aerial intersection. The «indoor inside» values are calculated for polygons of cadastres, which are fully situated inside the contours of the geological unit. The «indoor centroid» values correspond to geographical centroids of cadastres, which lie inside the contour of the geological unit, but the polygon of cadastre can intersect partially the contour of the geological unit. The values placed in shaded columns in table II approve the relationship of mean soil gas radon values in rock types and mean indoor radon values.

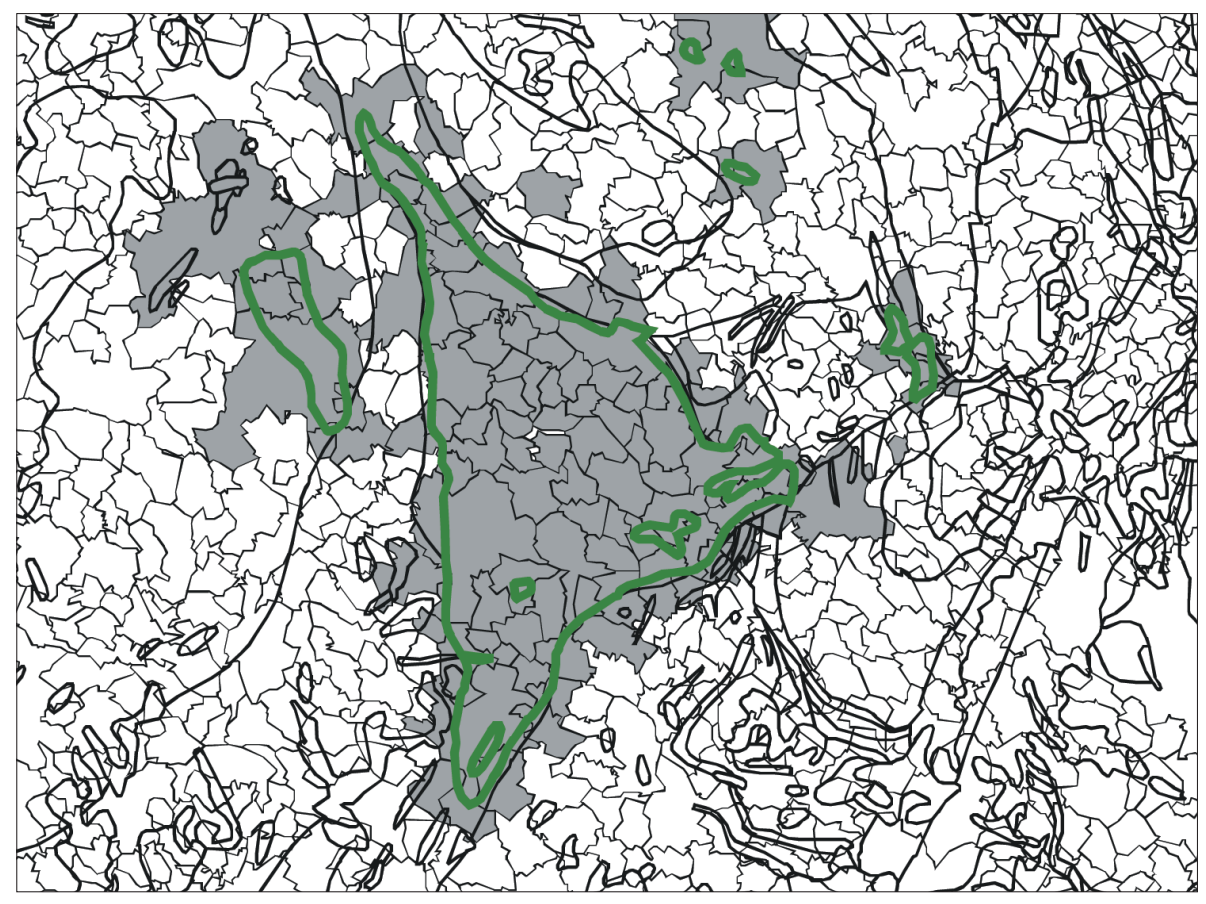

Fig. 1. The selection of cadastres performed by simple intersection of cadastres and contours of durbachite bodies (bold outlined). 


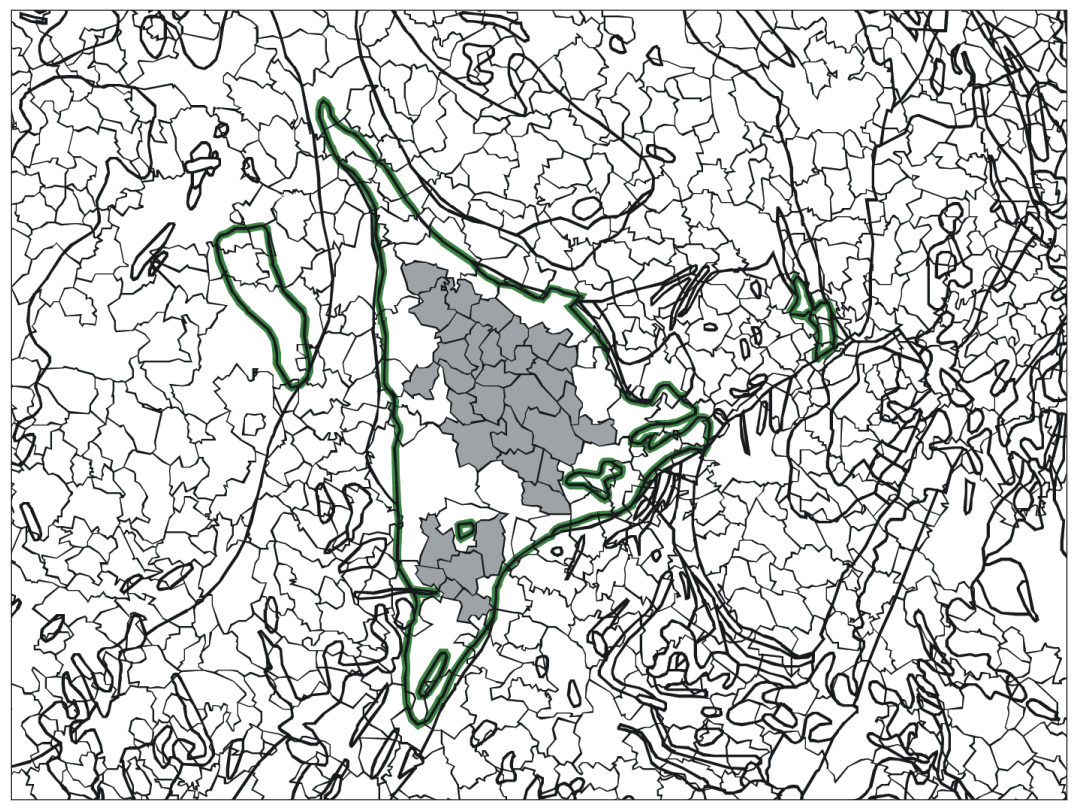

Fig. 2. The selection of cadastres based on placing the polygons of cadastres inside contours of durbachite bodies (bold outlined) without intersecting.

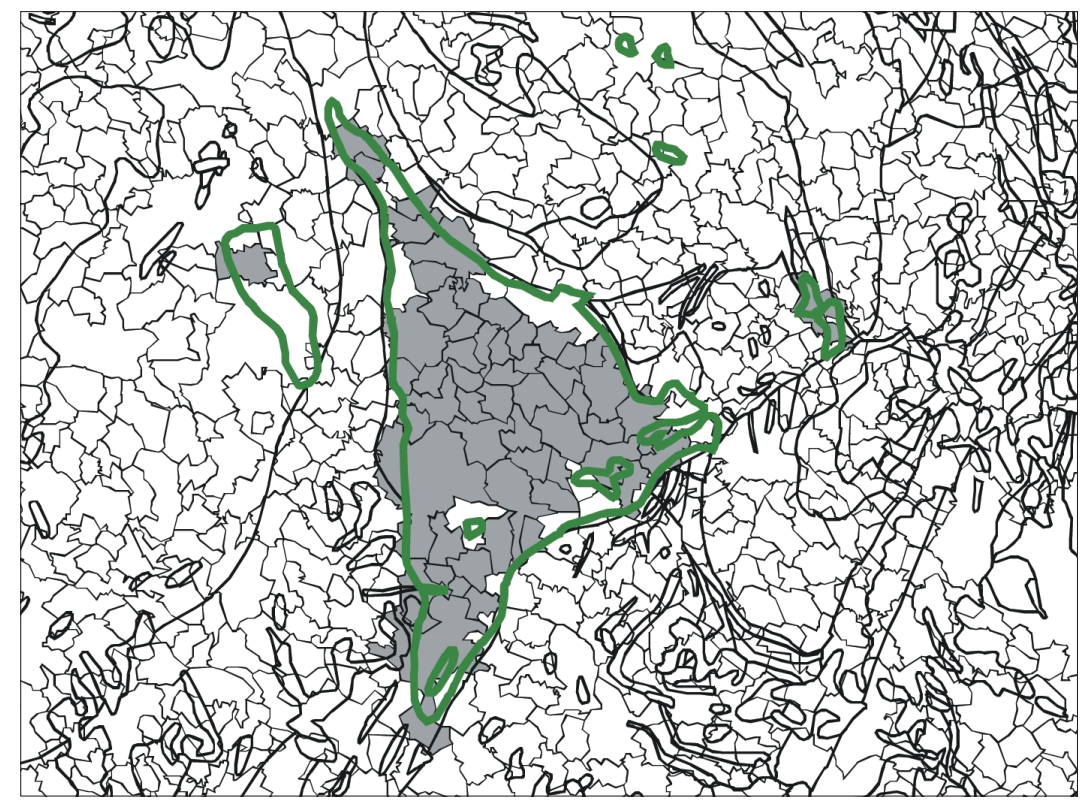

Fig. 3. The selection of cadastres based on placing the centroids of cadastres inside the rock contours plus intersecting the contours of durbachite bodies (bold outlined). This selection represents the shape of rock body most precisely. 
Table II.The values of indoor radon geometric means in major rock types calculated by three different methods.

\begin{tabular}{|c|c|c|c|c|c|c|c|c|}
\hline \multirow[t]{2}{*}{ Major rock types } & \multicolumn{6}{|c|}{ Indoor Rn (means $\mathrm{Bqm}^{-3}$ ) } & \multicolumn{2}{|c|}{$\begin{array}{c}\text { Soil gas Rn } \\
\left(\text { means } \mathrm{kBqm}^{-3}\right)\end{array}$} \\
\hline & $\begin{array}{l}\text { Indoor } \\
\text { intersection }\end{array}$ & $\begin{array}{l}\text { No. } \\
\text { int }\end{array}$ & $\begin{array}{l}\text { Indoor } \\
\text { inside }\end{array}$ & $\begin{array}{l}\text { No. } \\
\text { ins }\end{array}$ & $\begin{array}{l}\text { Indoor } \\
\text { centroid }\end{array}$ & $\begin{array}{l}\text { No. } \\
\text { cent }\end{array}$ & $\begin{array}{c}\text { Mean } \\
\text { rock }\end{array}$ & $\begin{array}{l}\text { No. } \\
\text { rock }\end{array}$ \\
\hline $\begin{array}{c}\text { Moldanubian paragneisses } \\
\text { - Monotonous series }\end{array}$ & 99.24 & 570 & 116.96 & 79 & 100.53 & 275 & 28.08 & 528 \\
\hline $\begin{array}{l}\text { Moldanubian crystalline } \\
\text { rocks - Variagated series }\end{array}$ & 104.2 & 464 & 91.27 & 42 & 95.19 & 236 & 31.25 & 465 \\
\hline $\begin{array}{l}\text { Proterozoic - phyllites, } \\
\text { metamorphosed shales }\end{array}$ & 95.81 & 1062 & 101.76 & 54 & 94.69 & 470 & 26.61 & 345 \\
\hline $\begin{array}{l}\text { Orthogneisses, granulites, } \\
\text { migmatites - Moldanubian }\end{array}$ & 106.01 & 583 & 109.49 & 23 & 110.62 & 181 & 32.05 & 383 \\
\hline $\begin{array}{l}\text { Ultrabasic rocks } \\
\text { - Moldanubian }\end{array}$ & 96.03 & 51 & 0 & 0 & 139.93 & 3 & 17.2 & 4 \\
\hline Granitoids - Cadomian & 89.89 & 192 & 80.6 & 3 & 95.74 & 59 & 17.2 & 155 \\
\hline $\begin{array}{c}\text { Palaeozoic } \\
\text { - metamorphosed }\end{array}$ & 91.1 & 201 & 103.75 & 2 & 96.18 & 87 & 39.25 & 154 \\
\hline $\begin{array}{c}\text { Palaeozoic } \\
\text { - unmetamorphosed }\end{array}$ & 93.7 & 552 & 102.65 & 121 & 99.51 & 320 & 27.92 & 402 \\
\hline $\begin{array}{c}\text { Volcanites - Proterozoic, } \\
\text { Palaeozoic }\end{array}$ & 91.12 & 606 & 64.4 & 2 & 97.13 & 99 & 37.11 & 45 \\
\hline Granites - Variscan & 104.32 & 547 & 128.64 & 36 & 105.98 & 209 & 58.8 & 424 \\
\hline Granodiorites - Variscan & 152.38 & 390 & 203.09 & 39 & 177.86 & 197 & 66.3 & 307 \\
\hline Durbachites, syenites & 205.36 & 165 & 334.91 & 39 & 272.3 & 77 & 56.78 & 180 \\
\hline Diorites, gabbros - Cadomian & 107.67 & 133 & 0 & 0 & 87.23 & 20 & 22.63 & 55 \\
\hline Mesozoic - Alpine folding & 54.39 & 128 & 47.53 & 4 & 52.74 & 53 & 17.35 & 1788 \\
\hline Tertiary - Alpine folding & 65.22 & 429 & 71.76 & 53 & 67.15 & 273 & 20.28 & 759 \\
\hline Permocarboniferous & 74.46 & 515 & 72.36 & 20 & 75.29 & 234 & 33.72 & 326 \\
\hline Mesozoic - sediments & 62.23 & 1224 & 60.46 & 67 & 60.72 & 590 & 17.53 & 1788 \\
\hline Tertiary - sediments & 78.35 & 820 & 66.99 & 9 & 72.57 & 192 & 20.28 & 759 \\
\hline Neovolcanites - Tertiary & 65.47 & 306 & 69.2 & 3 & 60.64 & 52 & 21.55 & 35 \\
\hline Quaternary & 73.06 & 2274 & 73.25 & 199 & 68.57 & 1003 & 25.37 & 525 \\
\hline
\end{tabular}

\section{Software platform}

The source soil radon gas database was based on Visual FoxPro, for predictive radon risk map production converted to Oracle 8i. The data model for geological maps was originally created in ArcInfo (ESRI Corp.). Later this model was converted into MicroStation (Bentley Systems Corp.) - MGE (Intergraph Corp.) Oracle (Oracle Corp.). This model was also used for radon risk maps formation. The spatial analyses were done in ESRI software Arc GIS.

\section{Outputs}

In 1998 the CGS issued the Digital Atlas GEOCR500 - the geological, radiometric and radon risk maps on the scale $1: 500000$ together with eight maps with geoscientific topic. This radon risk map was based on the vectorized contours of geological units and on the results of gamma dose rate measurements.

This Atlas was published on CD-ROM in GIS project for ArcView 3.0 (Barnet and Mikšová, 2001). 


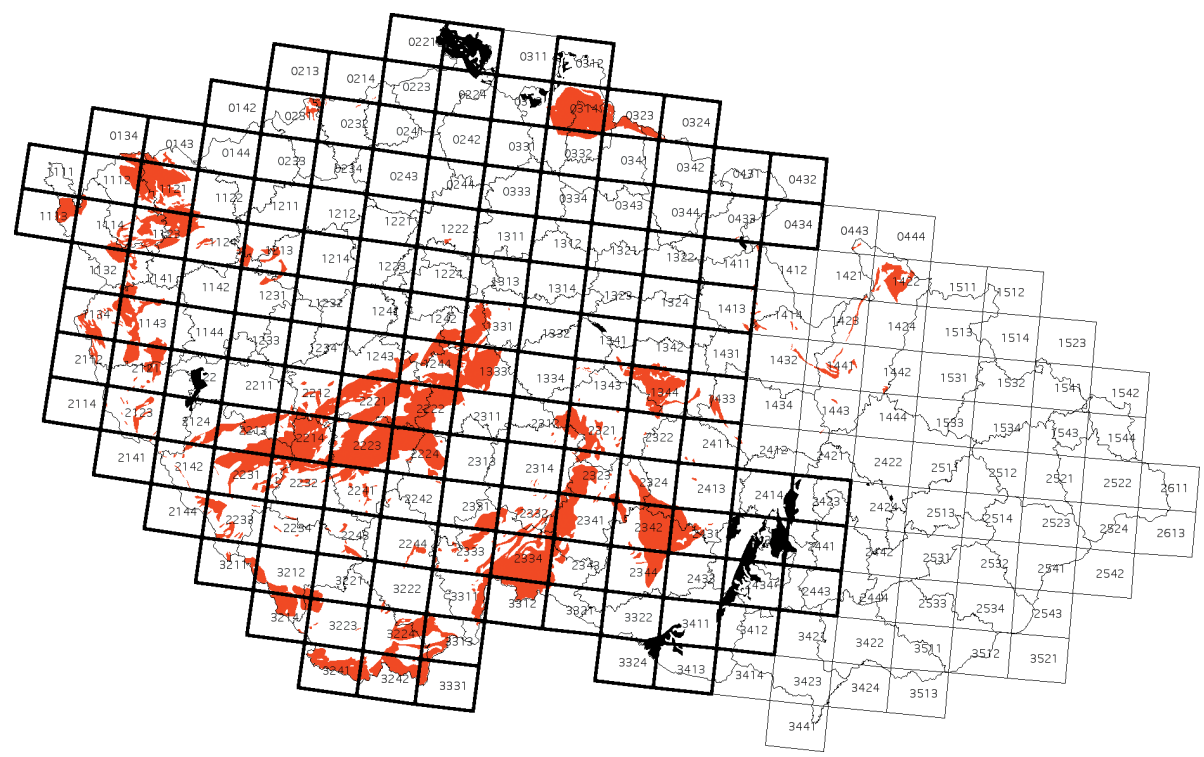

Fig. 4. Czech Republic-completed radon risk map sheets 1:50 000 (bold framed). The priority of map sheets processing was oriented to cover dominantly the extent of granitoid bodies within the Czech Republic.

In 1998 the CGS finished the vectorization of geological maps at the scale $1: 50000$. These maps covered the whole state territory.

This fact allowed the formation of more detailed radon risk maps based on geological maps. Since 1999 about 154 map sheets of Radon risk maps at the scale 1:50 000 (from total number of 214 sheets) have been published up to 2003 (fig. 4). These maps are available in digital and printed form. The digital outputs are published on CD-ROM.

The selection from the mosaic map enables to open the full view of the map and detailed view of four single quadrants. The points of the test sites are linked to the selected items from the radon database in a separate window.

\section{Conclusions}

By comparing the values of radon concentration in dwellings and the measured values on the test sites in geological units, the close correlation between the radon concentration and geological bedrock was established, especially in the areas where igneous and metamorphosed rocks were found.

The data processing based on vectorized geological maps was proven as a highly efficient and relevant tool for determination areas where increased indoor radon values caused by radon exhalation from bedrock can be detected.

After verification of the efficiency of track etch detectors placed in dwellings with the help of prognostic radon risk maps at the scale of 1:50000, $75 \%$ reliability of these maps was proven.

The outputs of geological research are used by regional centers of SONS and municipal authorities to set the priority for distributing the track-etch detectors in dwellings. In the case of randomly distributed track-etch detectors only $2 \%$ of measured dwellings exceeded the guidance level $200 \mathrm{~Bq} \mathrm{~m}^{-3}$ EEC. Using radon risk maps on a scale 1:50 000 for setting of detectors into areas with assumed medium or high radon risk category in bedrock the number of affected dwellings increased to $20 \%$. 
Predictive radon risk maps were issued by CGS in the form of printed maps or on interactive CD-ROM in GIS projects.

Presentation of radon research work, especially radon risk mapping, are accessible to the wider public on the portal of CGS - www.geology.cz radon mapping - in Czech and English versions.

\section{REFERENCES}

BARNET, I. (1996): The research project No. 3310 Radon Risk in the Czech Republic - The activities of the Czech Geological Survey, in Third International Workshop on the Geological Aspects of Radon Risk Mapping, edited by I. BARNET and M. NeZnAL, Prague, 1-9.

BARnET, I. and J. MikŠovÁ (2001): The GIS approach to radon risk mapping in the Czech Republic, in Proceedings of the «5th International Conference on Rare Gas Geochemistry», Debrecen, Hungary, 189-196.

BARnET, I., J. MiKŠovÁ and I. FoJTIKovA (2002): The GIS analysis of indoor radon and soil gas radon in major rock types of the Czech Republic, in Radon investigations in Czech Republic IX and the sixth international workshop on the geological Aspects of Radon Risk Mapping (Czech Geol. Surv. and Radon Comp.), Prague, 5-11.

Czech Technical Norm 730601 (1996): Protection of Building Against Radon from Soil (CNI, Prague), pp. 27.

Kemski, J., A. Siehl, R. Stegemann and M. ValdiviaMANCHEGO (2000): Mapping the geogenic radon potential in Germany, in Proceeding Workshop Radon in the Living Environment, Athens, Greece, 645-663.

KIES, A., A. BIELL and L. Rowlinson (1996): Radon survey in the grand-duchy of Luxembourg - Indoor measurements related to house features, soil, geology and environment, Environ. Int., 22, 805-808.

MiKŠOvÁ, J. and I. BARNET (2002): Geological support to the National Radon Programme (Czech Republic), Bull. Czech Geol. Surv., Prague, 77 (1), 13-22.

Mísař, Z., A. Dudek, V. Havlena and J. Weiss (1983): Geology of CSSR, I. Bohemian Massif (SPN, Prague), pp. 333 (in Czech).

POPIT, A. and J. VAUPOTIC (2002): Indoor radon concentrations in relation to geology in Slovenia, Environ. Geol., 42, 330-337. 